\title{
The Effect of Hand Hygiene Strategy on Internship Nurses Compliance at Alexandria University Hospitals: An Empirical Interventional Study
}

\author{
Sanaa Mohamed Alaaeldin,Professor ${ }^{1}$, \\ RashaAlyyakoutAly Hussein, Lecturer ${ }^{2}$ \\ Medical Surgical Nursing, Faculty of Nursing, Alexandria University \\ Medical Surgical Nursing, Faculty of Nursing, Alexandria University.
}

\begin{abstract}
Non-compliance with hand hygiene (HH) protocols in hospitals, particularly, is widely recognized as one of the most important contributing and preventable causes of health associated infections. Hence, continuing efforts are being made to identify effective and sustainable strategies to improve HH compliance. Aim:Determinethe effectof hand hygiene strategy among internship nurses on their compliance at different Alexandria University Hospitals.

Setting: This study was carried out in six hospitals in Alexandria which all the internship nurses of the Faculty of Nursing have been trained; the MainUniversity, Elhadara, Elshatby, SmouhaUniversity, Student University, and ElmoassatAlexandria University Hospitals. All nurses were enrolled to 5 departments to attain their internship year specialty requirements; Medical-Surgical, Critical, Administration, Pediatric, and Obstetric\&Gynecologic departments.
\end{abstract}

Subjects:Subjects of this study comprised all internshipnurses (n=190) available at the previously mentioned settings and providing direct patient 'care.

Tools:Two tools were used to collect the data; tool I: Hand hygiene 5moments observation form; was used to measure (HH) compliance after an interventional strategy. Tool II: Hand hygiene intervention strategy, three-phase intervention strategies were provided to all internship nurses at different University Hospitals settings.

Results: Themean score of the internship nurses compliance to HH action in the Pediatric department was much better than in Obstetric\&Gynecologic one month as well as three months post interventional strategyat both morning and evening shifts. Critical care department showed higher mean score compliance throughout the 5 indications the morning and evening shifts (38.9\%, 46.0\% respectively), while the Administration department showed the lowest mean score of compliance (19.4\%, 20.0\% consecutively).

Conclusions:Internshipnurses' compliancewas high in some departments after one month, and declined after three months post strategy. No marked differences were found between morning and evening shifts, in relation to HH compliance in some departments.

Recommendations: Compliance strategies should be implemented early and periodically in the clinical courses for internship nurses.

Keywords:Hand Hygiene (HH),HHcompliance, internshipnurses, and interventional strategy.

\section{Introduction}

Health-care-associated infections (HCAIs) are one of the most frequent issues of patient' safety worldwide $^{(1,2)}$. It remains a big concern that no organizationsor countries can claim to have solved as yet. (HCAIs) persists as a major and growing health problem, causing increased morbidity, prolonged hospital stay, and a high number of in-hospital deaths ${ }^{(3,4)}$.hundreds of millions of patients around the world each year are affected by (HCAIs) ${ }^{(3)}$.

Healthcare-associated pathogens that can lead to infection are transmitted through direct and indirect contact, droplets, air, and the contaminated hands of healthcare workers (HCWs).Theyare the most common vehicles of transmission in most settings ${ }^{(5)}$. Hand contamination increases with increasing time spent providing direct patient care, and in the absence of appropriate hand hygiene ${ }^{(5)}$ Among different hospital specialties, intensive care units (ICUs) are consistently found to have the highest prevalence rate of (HCAIs), when compared to other units in the hospitals ${ }^{(6)}$.Hand hygiene, either by hand washing or hand disinfection, remains the single most important measure to prevent (HCAIs) ${ }^{(7)}$. Optimal hand hygiene behavior is considered the cornerstone of (HCAIs) prevention ${ }^{(8,9)}$. Furthermore, not only it is a key element of standard and isolation precautions, but its importance is emphasized also in the most modern 'bundle' approaches for the prevention of specific site infections such as catheter-related bloodstream infection (CRBSI), catheter-related urinary tractinfection (CRUTI), surgical site infection (SSI), and ventilator-associated pneumonia (VAP) ${ }^{(10,11)}$.Noncompliance with HHprotocols in hospitals, particularly, is widely recognized as one of the most important 
contributing and preventable causes of HAIs ${ }^{(12)}$. Several studies have reported that compliance to HH remains inefficient and needs corrective actions to be sustained. Average adherence with hand hygiene' recommendations is usually estimated to be below $50 \%$, but varies between different hospital settings, among professional categories, and according to working conditions the world health organization (WHO) has compiled guidelines in this regard in order to reduce the prevalence of $\mathrm{HCAI}^{(13,14)}$

Furthermore, many studies done to assess the knowledge, attitudes, compliance and reasons for nonadherence of $\mathrm{HH}$ by health care workers;denoted pooradherence to $\mathrm{HH}$,due to several constraints including; high number of clinical procedures, lack of appropriate equipment, low staff to patient'ratios, allergies to hand washing products, and insufficient knowledge among staff about risks procedures, the time required and casual attitudes among HCWs towards bio-safety ${ }^{(15,16,17)}$.Students in their clinical training phase throughout the healthcare facilities can potentially transmit infections besides being the healthcare providers of future, their patterns of training will reflect on their infection control practices. Multiple studies that have been conducted to study HHpractices among nursing and medical students, found that medical students have anoverall lower rate of $\mathrm{HH}$, compared to nursing students ${ }^{(18,19)}$.

To address the problem of lack of compliance with $\mathrm{HH}$, published studies has increased considerably in recent years, with questions about improved adherence to recommended policies remaining unanswered ${ }^{(20,21)}$.Continuingefforts are being made, to identify effective and sustainable strategies. One of such efforts is the introduction of an evidence-based concept of "my five moments for hand hygiene" by WHO. These five moments that call for the use of HHinclude the moment before touching a patient, before performing aseptic and clean procedures, after being at risk of exposure to body fluids, after touching a patient, and after touching patient' surroundings. This concept has been properly used to improve understanding, training, monitoring, and reporting hand hygiene among healthcare workers ${ }^{(22)}$.

Most studies have explored the knowledge, attitudes and practices of doctors and nurses with only a few including nursing students. The primary training of these groups is the responsibility of the faculty and the hospital where they receive their initial training ${ }^{(18,21,23)}$. Moreover, HH guidelines need to be taught to student nurses in their first semester, before their first clinical placement at a time when they may have no healthcare experience ${ }^{(24)}$. So, the present study seeks to explore the effect tohand hygiene strategy among internship nurses on their compliance at different settings. This would be useful in identifying gaps in knowledge, poor attitudes and substandard practices to improve existing training strategies and enhance good practices and work ethics in the future.

\section{Aim oftheStudy}

This study aimed to determinethe effect of hand hygiene strategy among internship nurses on their compliance at different Alexandria University hospitals.

\section{Research Hypothesis}

Internship nursesattending hand hygiene strategy hadhigher compliancemean practice scores post strategy than before?

\section{Research Design:}

\section{Materials And Methods}

A quasi experimental study design was used to conduct this study.

\section{Setting}

This study was carried out atsixUniversity teaching hospitals in Alexandriain which all the internship nurses of the faculty of nursing are trained;namely the Main university ,Elhadara,Elshatby, Smouha, Student, and El-Moassat Alexandria university hospitals. All nurseswererecruited to 5 departments to fulfill their internship yearrequirements at Medical-Surgical, Critical, Administration, Pediatric, and Obstetricspecialties departmentsas follow;

1. Medical-Surgical Nursing (MSN)Department:all the internship nurses were enrolled to different units in three hospitals as follows;

a. Main University hospital's units as; Burn ICU, Neuro-surgery ICU,Medical ICU, and Operating rooms related to; Cardio-Thoracic, Plastic, Headand Neck, and Urosurgeries.

b. Elhadaraunits as; NeuropsychiatryICU, Orthopedic surgery, Critical and Epilepsy ICU and Orthopedic ICU.

c. El-Moassatdialysis unit.

2. Critical Nursing Specialties (CN): Emergency (ER), Recoveryrooms (RR), Thoracic ICU and general ICU

3. Nursing Service Administrationspecialties(NA):The Intensive Care UnitsICU.

4. Pediatric Nursing Specialties (PN):Pediatric neonatal Intensive Care Unit (NICU), Pediatric Intensive Care Unit (PICU). 
The Effect of Hand Hygiene Strategy on Internship Nurses Compliance at Alexandria University ...

5. Obstetric\&Gynecologicnursing Specialties(Obs\&Gyn): All the internship nurses were rotated toElshatbyhospital at the Obstetric ICU.

Subjects:

The subjects of this study comprised all internship nurses (190)availableat the previously mentioned academic nursing departments, and providing direct patient care namely; 83 from the Critical care , 4 from Nursing service Administration, 60 from Medical- Surgical , 35 from Pediatric, and 8 from ObstetricNursing.

Tools:

Twotools were used to collect the necessary data:tool I: Hand Hygiene 5 Moments Observation Form: this was adapted from the original WHO5 moments "Observation Form"(2009) and was modified after reviewing the related literature $^{(13)}$. It wasused to measure $\mathrm{HH}$ compliance after an interventional strategy. It included two parts;

Part I: This part included items related to basic data in relation to;facility,service, hospital department,phase (pre or postintervention), date, start/end time, session duration (difference between start and end time), session $\mathrm{n}^{\circ}($ attributed at the moment of data entry for analysis),observername, (interns nurse ' name, group and academic year) and number of observed interns nurse.

Part II:This part includedindications inHH 5 moments Observation Formas; Opportunity(name of procedure that was done in the shift), indications (all 5 indications that apply at one moment must be recorded) as follow;1.bef.pat: before touching a patient,2.bef.asept: before clean/aseptic procedure, 3.aft.b.f: after body fluid exposure risk, 4.aft.p: after touching a patient, 5.aft.p.surr: after touching patient 'surroundings. $\mathrm{HH}$ actions response to the hand hygiene indication(s); it can be either HR: hand hygiene action by rubbing with alcohol (70\%), or HW: washing with soap and water,missed: no HH action performed, or improper: improper hand washing by not following all the steps of HW/HR. The opportunityexistswhenever one of the indications for $\mathrm{HH}$ occurs and is observed in nursing procedures as; (changing dressing, IM or S.Cinjections, suction, nasogastric feeding, measuring CVP, range of motion exercise, patient's care, givingmedication, e.g, bloodsample, ABG, IV infusion, blood transfusion, preparing\& administering of anesthetic medications ,assessment \& preparing epidural catheter , preparation \& insertion of foleycatheter ,insertion of venous catheter, connection \& disconnection of patient from dialysis machine, and shunt care.

Tool II:Hand Hygiene Interventionalstrategy: This strategyaimed to improve the study nurses practice of hand hygiene. It included four phases:

Phase I:Intervention Stage.

-The intervention took the form of theory and clinical training. Two sessions for all the participant nurses in the study were given about the necessity, time, correct steps of hand washing as well as hand rub, suggested plans to enhance hand washing, the application of the WHO five moments. Written leaflets were provided to the all participant nursesabout5moments $\mathrm{HH}$, and WHO HH (washing/disinfection)steps.

-Evaluation for every internship nurse was done immediately after the clinical training sessions by using HW/HR observational checklist.

Phase II:Post Intervention- Initial Follow Up:

Thisphase started one month post strategy application.It included observationof internship nurses $\mathrm{HH}$ compliance usingHand Hygiene Moments 5 Observation Formthrough the internship nurse ' preceptors, who were assigned from the faculty of nursing to teach and evaluate every internship nurse.

Phase III:Post Intervention- Late Follow Up:

This phase startedthree months post strategy.it included observationof internship nurse ' $\mathrm{HH}$ compliance through the internship preceptor.

Compliance to $\mathrm{HH}$ using alcohol based hand rubbing and hand washing practices, were recorded against each opportunity. Every nursewas watched for three opportunities in the varied units.

Compliance to $\mathrm{HH}$ practices was assessed and scored from 0 to 3, where missed step scored as $(0)=$, improper step scored as $(1)=$, HW scored as $(2)=$, and HR scored as $(3)=$. The percent score ofcompliance in relation to $\mathrm{HH}$ actions wascalculated from 0 to 100 where; $(0)=0 \%,(1)=33.3 \%,(2)=66.7 \%$, and $(3)=100 \%$.

Compliance in relation to indications was assessed and scored by using percent scoring ranging from 0 to 15 , where $(0)=0 \%$, and $(15)=100 \%$ compliance . Then the percent score of compliance for every internship nurse was calculated as; total score of indications $/ 15 \%$. 


\section{Method}

1. Approvalto conduct the study was obtained from the responsible authorities of Alexandria Main University Hospitals, Elshatby, Smouha,Students, El-MoassatandElhadara Hospitals.

2. The studytoolswereadapted and modifiedbased on a review of the related literature ${ }^{(13)}$. Content validity was tested by 5 experts in the field of Medical-Surgical, Critical, Administration, Pediatric, and Obstetric, Gynecologic departments. Accordingly, all necessary modifications were introduced.

3. The reliability of the modifiedHand Hygiene Moments 5 Observation Form toolwas established by testing and retesting, on 20 Medical-Surgical internship nursing.

4. Apilot studywas carried out after toolmodification, on 5 internship nurses, in the previous mentioned settings; to ensure clarity, applicability, and feasibility of the tool.

5. To minimize the differences between the observers, only one internship preceptor was recording observations,to every internship nurse regarding $\mathrm{HH}$ opportunities, and the number of actual $\mathrm{HH}$ events in every unit. Concealed observations were maintained, throughout the study data collection phase.

6. Data Collection:- Every preceptor was trained on how to apply all the strategy steps, and how to fill-in the observation checklist items. This checklist was used to observe internship nurse 'hand hygiene compliance during providing patient' care in her assigned department, throughout varied opportunities.

- Each time an observed internship student entered the patient zone from the health-care area, the preceptor observed him/her if follow the WHO "Five Moments For Hand Hygiene" in each procedure that was done for the patient or not.

- Observations were carried out for every internship nurse two times (initially one month post the interventional strategy, and the other ' three months later.

- Every nurse was observed on various days of the week throughoutthe morning and evening shifts, in all units except operating rooms (morning shifts only) to allow multiple observations of internship nurse 'compliance, obtain more representative results and to identify if differences existed between the two shifts.

- Observations were to the extent possible, without compromising patient care or privacy. Sinks for hand washing wereavailable at each unit in all hospital plus wall mounted dispensers containing $70 \%$ alcohol- based hand gel. The data were collected from the beginning of September 2016 till the end of December 2016.

\section{Statistical Analysis:}

Data were fed to computer and analyzed using IBM SPSS software package version 20.0. Qualitative data were described using number and percent. Quantitative data were described using mean, standard deviation. Significance of the obtained results was judged at the 5\% level. Chi-square test was used for categorical variables, to compare between different hospitals departments, Monte Carlo correction ; correction for Chi-square when more than $20 \%$ of the cells have expected count less than 5.in addition, f-test (ANOVA) was used to compare between more than two hospitals. P value of $\leq 0.05$ was used to assess the significance of the results.

\section{Results}

Table (1): Shows compliance perception of internship nurses regardingHH practice in the 5 indications throughout morning shiftpost strategyone and three monthsin Pediatric and Obstetric at Elshatbyhospital.After one month post the interventional strategy, the findings showed thatthepercent ofhand washing compliance among more than half of the internship nurses was highin the pediatric department in the 5 indications as well as in three opportunities.in the obstetric department, the results showed that more than half of the internship nurses complied with hand wash in some indications but more than one third of them were notcomplying, before touching patients and their surrounding (50.0\%, 37.5\% respectively). A significant difference was detected between the two departments; as $\mathrm{p}$ value $0.001 \%, 0.043 \%, 0.015 \%$ respectivelyafter touchingpatient surrounding, and beforetouching a patient. Three months post intervention; the findings showed that thepercent ofhand washing compliancewas decreasedas compared to one month later. In pediatrics, more than one third of the participantsdidn'tcomplyespecially before touching patients and aftertouchingthe surroundings $(42.9 \%, 48.6 \%$, and $60.0 \%$ respectively). Regarding Obstetric, the table shows that half and more than half of the nurses didn't complyat all with $\mathrm{HH}$ action in almost all the5 indications. A highly statistical significant difference was present between the two departments.

Table (2): Portrays compliance perception of internship nurses regardingHH practice in the 5 indications throughout evening shiftpost strategyone and three monthsin Pediatric and Obstetric\& Gynecologic at Elshatby hospital.The findings revealed that one month post intervention the percent ofcompliance to hand washing and rub among the studiednurses, were prominentinthe Pediatric department in the 5 indications of the 
three opportunities. In relation to Obstetric department, the table shows that half and more than half of the nursesdidn't complyto hand washing in the 5 indications, while $37.5 \%$, and $50.0 \%$ of them didn't complybefore touching patients and aftertouchingthe surroundings. a highly statistical significant difference was observed between the two departmentsbeforetouching patient, after body fluid exposure risk, and after touching patient surrounding $(0.045 \%, 0.023 \%, 0.014 \%, 0.018 \%, 0.004 \%, 0.001 \%$, and $0.040 \%$ respectively)in the three opportunities. Threemonths post intervention, the table shows that thepercent ofcompliance significantlydeclined as compared after one month in the Pediatric department regarding three opportunities $(57.1 \%, 8.6 \%, 42.9 \%$ respectively). on the other hand(45.7\%, $40.0 \%, 51.4 \%, 48.6 \%)$ of participants were non-complying to $\mathrm{HH}$ after body fluid exposure risk, afterand before touchingpatients and aftertouching surroundings. in relation to obstetric department, the findings show that more than half of the study sample were non- compliant to $\mathrm{HH}$ as compared to the first month. A highly statistical significant difference was evident between the two departments.

Figure (1): Illustrates comparisons between the mean value of the compliance perception to $\mathrm{HH}$ action in the5 indications throughout the morning and evening shiftspost strategyone and three months in Pediatric and Obstetric departmentsat Elshatby hospital. The findings reveals thatthemean percent score of the nurses compliance to $\mathrm{HH}$ action in the Pediatric department was much better than in Obstetric after one as well as three months post intervention at both shifts. Moreover, the figure shows that themean percent score of compliance to HHaction in the Pediatric department was markedly decreased three months post intervention than before $(67.62 \%, 52.78 \%$ respectively $) \&(44.57 \%, 44.25 \%$ respectively $)$

Table (3): Conveys comparison among the different departments according to compliance perceptionat the Main university, Smouha, Student, and El-MoassatAlexandria University Hospitals. After one month, the results showed that ICU unit had the highest mean/standard deviation of compliance compared with other unitsone month post $\mathrm{HH}$ intervention at both shifts(57.92 $\pm 24.55,72.92 \pm 13.87,70.0 \pm 10.33,80.0 \pm 8.78$, 75.42 \pm 6.76 , and 77.50 \pm 9.07 respectively). For Administration departments, it was noted that the mean percent score of compliance was high atevening shift than the morning $(65.0 \pm 12.62,63.33 \pm 11.55$ consecutively). OR unit's nurses showed higher mean percent score of compliance in all opportunities in the morning and evening shifts than other Medical-Surgical units $(70.67 \pm 16.06,40.0 \pm 16.33,46.67 \pm 28.67,72.0 \pm 15.20,52.0 \pm 24.68$, $52.0 \pm 30.33$ respectively). Significant differences found amongdifferent departments. The table shows an observable decrease in the mean percent of compliance of the nurses three months post $\mathrm{HH}$ interventional strategyboth atmorning and evening shifts as compared to theinitial follow up. The mean percent of compliance in the ICU was decreased than before in both shifts $(39.58 \pm 14.29,57.50 \pm 16.31,52.08 \pm 17.42,60.42 \pm 13.44$, $50.0 \pm 21.50$, and 52.08 \pm 14.85 respectively), and in Administration departments $(15.0 \pm 11.39,25.0 \pm 17.53$, $18.33 \pm 10.0,21.67 \pm 10.0$, and $20.0 \pm 10.89$ consecutively). In relation to the Medical- Surgical departments, the results show that the mean percent of the nurses' compliance in the Urology unit was markedly improved than before $(37.78 \pm 10.18,46.67 \pm 6.67,28.89 \pm 19.25,42.22 \pm 10.18,53.33 \pm 13.33$, and $62.22 \pm 21.43$ respectively). Positive statistical significant differences existed among the different departments $(\mathrm{p}=0.033,0.001$ respectively).

Table (4): Portrays comparison between the different departments according to compliance perceptionat Elhadara hospital: the results revealed positive significant differencesamongthe three units one month as well as three months post $\mathrm{HH}$ intervention at morning and evening shifts. after one month, the Epilepsy ICU had a higher percent score of nurses compliance as compared to the other units both atmorning, andevening shifts $(73.33 \pm 9.43,63.33 \pm 6.67,75.0 \pm 10.0,81.67 \pm 10.0$, and $65.0 \pm 16.67$ respectively). After three months of $\mathrm{HH}$ intervention, in spite of the markeddecline in the mean score of the nurses'compliance throughout all units in the morning and evening shifts, Epilepsy ICU unit still had a high percent score of the compliance of the subjects as compared to the other units in the three opportunities $(37.22 \pm 17.63,37.22 \pm 13.77,42.78 \pm 14.90,45.0 \pm$ $27.95,30.0 \pm 19.25$, and $33.33 \pm 18.05$ consecutively).

Table (5): Shows compliance perception of internship nurses regardingHH practice in the 5 indications throughout morning shiftpost strategyone and three monthsat the main university/Elhadarahospital. In relation to Critical care department; the table shows that more than one quarter of the internship nurses became compliant one month after the educational intervention of hand washing in the5 indications. Regarding Administration department, half and more than half of the study subjects were compliant in relation to hand washing as well as rub in 5 indications. Concerning Medical- Surgical department, the table denotes that noncompliance was observed in more than one quarter of the nurses, especially before and aftertouchingpatients, aftertouchingpatient surrounding, and before clean/aseptic proceduretechnique in the three opportunities. There 
were statistical significant differences among the three departments $(\mathrm{p}=0.026 \%, 0.001 \%, 0.007 \%, 40.0 \%, 0.029$ $\%$ respectively). However, after three months, there was a significant decline in the mean percent score of subjects' compliance in the three departments. Concerning the Critical care department, the results concluded that the majority of the internship nurseshad missed /improper HH in the 5 indications in the three opportunities. Regarding the Administration,Medical- Surgical departments, it was observed that all the nurses were non compliantregarding $\mathrm{HH}$ actions in the 5 indications. Statistical significant difference among the three departments, were detected $(\mathrm{p}=0.049 \%, 0.003 \%, 0.001 \%, 0.038 \%, 0.036$, and $0.002 \%, 0.016 \%$ consecutively).

Table (6): Portrays compliance perception of internship nurses regardingHH practice in the 5 indications throughout evening shiftpost strategyone and three months atthe main university/Elhadarahospital. After one month, there were statistical significant differencesamong the three departments. Regarding Critical care department; the table shows that all the study nursescomplied to hand washing in 5 indications. In relation toAdministration department, the findings showed that the percent of compliance to (HW/HR) was markedly high among all the nurses in the 5 indications after implementation of educational intervention throughout the three opportunities. concerning Medical- Surgical department, the table denotes thatmore than one quarter of nurses were compliant in relation to hand washing in almost the 5 indications in spite of more than one quarterof themwere non- compliant especially before and after touching patients, after touching patient surrounding, and before clean/aseptic technique in the three opportunities $(40.0 \%, 43.3 \%, 36.7 \%, 31.7 \%, 35.0 \%$, consecutively). Three months later, it was found that hand washing compliance was observed in more than one quarterof the study nurses in Critical care department. In contrast to these findings, the table showed that all the nurses noncompliant to $\mathrm{HH}$ in all 5 indications throughout the three opportunities in Administration andMedical- Surgical department. There were statistical significant differencesamong the three departments $(\mathrm{p}=0.006 \%, 0.004 \%$, $0.001 \%, 0.003 \%$, and $0.019 \%$ consecutively).

Figure (2):Demonstrates comparison among the mean value of the compliance perception of internship nurses regarding $\mathrm{HH}$ practice in the 5 indications throughout morning and evening shifts post strategyone and three monthsin Critical, Administration, and Medical- Surgical departmentsat the Main university and Elhadara hospital. The figure reveals thatone month post $\mathrm{HH}$ intervention, themean percent value of the internship nurses compliance to $\mathrm{HH}$ action in the Critical care departmentwas much better than in Administration and Medical- Surgical department (60.4\%, 57.2\%, 46.0 \% respectively)in the morning shift as compared to evening shift, the Administration department showed higher mean percent ofcompliance to $\mathrm{HH}$ action than those in the other two departments(69.4\%, 65.5\%, 50.8\% consecutively). On the other hand, three months post intervention, the figure conveys that these mean percent values were markedly decreased as compared to after one month. Moreover, Critical care department showed highermean percent score of compliance throughout the 5 indications in the three opportunities both atmorning as well as evening (38.9\%, $46.0 \%$ respectively). Administration department showed the lowest mean percent score of compliance $(19.4 \%$, 20.0 consecutively) in the morning as well as in the evening.

Figure (3): Portrays comparison between different departments in the three hospitals according to the compliance perception of internship nurses regardingHH practice in the 5 indications throughout morning and evening shifts post strategyone and three months. The follow up revealed that, the highest mean percent score of the participants' compliance to $\mathrm{HH}$ action was in the Pediatric department in both morning and evening shifts $(67.6 \%, 68.5 \%, 44.6 \%$, and $44.3 \%$ respectively). On the other hand, the figure shows that the Medical- Surgical department had the lowest mean percent score of the nurses' compliance throughout the 5 indications in the three opportunities $(46.0 \%, 50.8 \%, 27.0 \%$, and $26.5 \%$ respectively). 
The Effect of Hand Hygiene Strategy on Internship Nurses Compliance at Alexandria University ...

Table (1):Distribution of compliance perception of internship nurses regarding $\mathrm{HH}$ practice in the 5 indications throughout morning shift post strategy one and three months in Pediatrics and Obstetric\&Gyne at

Elshatby hospital. $(\mathrm{n}=43)$

\begin{tabular}{|c|c|c|c|c|c|c|c|c|c|c|c|c|}
\hline \multirow{3}{*}{\multicolumn{3}{|c|}{ Morning shift }} & \multicolumn{9}{|c|}{ EI Shatby } & \multirow{4}{*}{${ }^{\mathrm{MC}} \mathbf{p}$} \\
\hline & & & \multicolumn{4}{|c|}{ Month 1} & \multirow{3}{*}{${ }^{\mathrm{MC}} \mathbf{p}$} & \multicolumn{4}{|c|}{ Month 3} & \\
\hline & & & \multicolumn{2}{|c|}{$\begin{array}{l}\text { Pediatrics } \\
\quad(n=35)\end{array}$} & \multicolumn{2}{|c|}{$\underset{(n=8)}{\text { Obstetric }}$} & & \multicolumn{2}{|c|}{$\begin{array}{l}\text { Pediatrics } \\
\quad(n=35)\end{array}$} & \multicolumn{2}{|c|}{$\begin{array}{l}\text { Obstetric } \\
(\mathrm{n}=8)\end{array}$} & \\
\hline Oppo. & Indications & Action & No. & $\%$ & No. & $\%$ & & No. & $\%$ & No. & $\%$ & \\
\hline \multirow{5}{*}{ Opp1 } & $\begin{array}{c}\text { Before touching } \\
\text { patient }\end{array}$ & $\begin{array}{c}\text { Missed } \\
\text { Improper } \\
\text { Hand washing } \\
\text { Hand rub }\end{array}$ & $\begin{array}{c}3 \\
0 \\
26 \\
6\end{array}$ & $\begin{array}{c}8.6 \\
0.0 \\
74.3 \\
17.1\end{array}$ & $\begin{array}{l}1 \\
1 \\
6 \\
0\end{array}$ & $\begin{array}{c}12.5 \\
12.5 \\
75.0 \\
0.0\end{array}$ & 0.180 & $\begin{array}{c}6 \\
0 \\
29 \\
0\end{array}$ & $\begin{array}{c}17.1 \\
0.0 \\
82.9 \\
0.0\end{array}$ & $\begin{array}{l}4 \\
1 \\
3 \\
0\end{array}$ & $\begin{array}{c}\mathbf{5 0 . 0} \\
12.5 \\
37.5 \\
0.0\end{array}$ & $0.008^{*}$ \\
\hline & $\begin{array}{c}\text { Before clean/ } \\
\text { aseptic technique }\end{array}$ & $\begin{array}{c}\text { Missed } \\
\text { Improper } \\
\text { Hand washing } \\
\text { Hand rub }\end{array}$ & $\begin{array}{c}3 \\
1 \\
20 \\
11 \\
\end{array}$ & $\begin{array}{c}8.6 \\
2.9 \\
\mathbf{5 7 . 1} \\
31.4 \\
\end{array}$ & $\begin{array}{l}1 \\
0 \\
6 \\
1\end{array}$ & $\begin{array}{c}12.5 \\
0.0 \\
75.0 \\
12.5\end{array}$ & 0.587 & $\begin{array}{c}4 \\
1 \\
29 \\
1\end{array}$ & $\begin{array}{c}11.4 \\
2.9 \\
82.9 \\
2.9\end{array}$ & $\begin{array}{l}1 \\
0 \\
7 \\
0 \\
\end{array}$ & $\begin{array}{c}12.5 \\
0.0 \\
87.5 \\
0.0\end{array}$ & 1.000 \\
\hline & $\underset{\text { Aluidexposure risk }}{\text { After body }}$ & $\begin{array}{c}\text { Missed } \\
\text { Improper } \\
\text { Hand washing } \\
\text { Hand rub }\end{array}$ & $\begin{array}{c}0 \\
3 \\
22 \\
10 \\
\end{array}$ & $\begin{array}{c}0.0 \\
8.6 \\
62.9 \\
28.6 \\
\end{array}$ & $\begin{array}{l}1 \\
0 \\
7 \\
0\end{array}$ & $\begin{array}{c}12.5 \\
0.0 \\
87.5 \\
0.0\end{array}$ & 0.085 & $\begin{array}{c}12 \\
2 \\
20 \\
1\end{array}$ & $\begin{array}{c}34.3 \\
5.7 \\
\mathbf{5 7 . 1} \\
2.9\end{array}$ & $\begin{array}{l}1 \\
2 \\
5 \\
0 \\
\end{array}$ & $\begin{array}{c}12.5 \\
25.0 \\
62.5 \\
0.0\end{array}$ & 0.330 \\
\hline & $\begin{array}{c}\text { After touching } \\
\text { patient }\end{array}$ & $\begin{array}{c}\text { Missed } \\
\text { Improper } \\
\text { Hand washing } \\
\text { Hand rub }\end{array}$ & $\begin{array}{c}5 \\
1 \\
15 \\
14 \\
\end{array}$ & $\begin{array}{c}14.3 \\
2.9 \\
42.9 \\
40.0\end{array}$ & $\begin{array}{l}3 \\
0 \\
5 \\
0 \\
\end{array}$ & $\begin{array}{c}37.5 \\
0.0 \\
62.5 \\
0.0\end{array}$ & 0.057 & $\begin{array}{c}7 \\
9 \\
19 \\
0 \\
\end{array}$ & $\begin{array}{c}20.0 \\
25.7 \\
\mathbf{5 4 . 3} \\
0.0 \\
\end{array}$ & $\begin{array}{l}4 \\
0 \\
4 \\
0 \\
\end{array}$ & $\begin{array}{c}\mathbf{5 0 . 0} \\
0.0 \\
\mathbf{5 0 . 0} \\
0.0\end{array}$ & 0.144 \\
\hline & $\begin{array}{c}\text { After touching } \\
\text { patient } \\
\text { surrounding }\end{array}$ & $\begin{array}{c}\text { Missed } \\
\text { Improper } \\
\text { Hand washing } \\
\text { Hand rub }\end{array}$ & $\begin{array}{c}11 \\
0 \\
8 \\
16\end{array}$ & $\begin{array}{c}31.4 \\
0.0 \\
22.9 \\
45.7\end{array}$ & $\begin{array}{l}1 \\
1 \\
6 \\
0\end{array}$ & $\begin{array}{c}12.5 \\
12.5 \\
75.0 \\
0.0\end{array}$ & $0.001^{*}$ & $\begin{array}{c}15 \\
2 \\
17 \\
1\end{array}$ & $\begin{array}{c}42.9 \\
5.7 \\
48.6 \\
2.9\end{array}$ & $\begin{array}{l}6 \\
0 \\
2 \\
0 \\
\end{array}$ & $\begin{array}{c}75.0 \\
0.0 \\
25.0 \\
0.0 \\
\end{array}$ & 0.449 \\
\hline \multirow{5}{*}{ Opp2 } & $\begin{array}{c}\text { Before touching } \\
\text { patient }\end{array}$ & $\begin{array}{c}\text { Missed } \\
\text { Improper } \\
\text { Hand washing } \\
\text { Hand rub }\end{array}$ & $\begin{array}{c}3 \\
1 \\
23 \\
8\end{array}$ & $\begin{array}{l}8.6 \\
2.9 \\
65.7 \\
22.9\end{array}$ & $\begin{array}{l}3 \\
1 \\
2 \\
2\end{array}$ & $\begin{array}{l}37.5 \\
12.5 \\
25.0 \\
25.0\end{array}$ & $0.043^{*}$ & $\begin{array}{c}17 \\
0 \\
18 \\
0\end{array}$ & $\begin{array}{c}48.6 \\
0.0 \\
51.4 \\
0.0\end{array}$ & $\begin{array}{l}6 \\
1 \\
1 \\
0\end{array}$ & $\begin{array}{c}75.0 \\
12.5 \\
12.5 \\
0.0\end{array}$ & $0.032^{*}$ \\
\hline & $\begin{array}{c}\text { Before clean/ } \\
\text { aseptic technique }\end{array}$ & $\begin{array}{c}\text { Missed } \\
\text { Improper } \\
\text { Hand washing } \\
\text { Hand rub }\end{array}$ & $\begin{array}{c}4 \\
2 \\
18 \\
11\end{array}$ & $\begin{array}{c}11.4 \\
5.7 \\
51.4 \\
31.4\end{array}$ & $\begin{array}{l}0 \\
0 \\
8 \\
0\end{array}$ & $\begin{array}{c}0.0 \\
0.0 \\
\mathbf{1 0 0 . 0} \\
0.0\end{array}$ & 0.118 & $\begin{array}{c}15 \\
1 \\
19 \\
0\end{array}$ & $\begin{array}{c}42.9 \\
2.9 \\
54.3 \\
0.0\end{array}$ & $\begin{array}{l}7 \\
0 \\
1 \\
0\end{array}$ & $\begin{array}{c}87.5 \\
0.0 \\
12.5 \\
0.0\end{array}$ & $0.055^{*}$ \\
\hline & $\begin{array}{c}\text { After body } \\
\text { fluidexposure risk }\end{array}$ & $\begin{array}{c}\text { Missed } \\
\text { Improper } \\
\text { Hand washing } \\
\text { Hand rub }\end{array}$ & $\begin{array}{c}3 \\
1 \\
20 \\
11 \\
\end{array}$ & $\begin{array}{c}8.6 \\
2.9 \\
\mathbf{5 7 . 1} \\
31.4 \\
\end{array}$ & $\begin{array}{l}1 \\
0 \\
7 \\
0\end{array}$ & $\begin{array}{c}12.5 \\
.0 \\
87.5 \\
.0\end{array}$ & 0.233 & $\begin{array}{c}4 \\
3 \\
26 \\
2\end{array}$ & $\begin{array}{c}11.4 \\
8.6 \\
74.3 \\
5.7\end{array}$ & $\begin{array}{l}1 \\
7 \\
0 \\
0\end{array}$ & $\begin{array}{c}12.5 \\
87.5 \\
0.0 \\
0.0\end{array}$ & $<0.001$ \\
\hline & $\begin{array}{c}\text { After touching } \\
\text { patient }\end{array}$ & $\begin{array}{c}\text { Missed } \\
\text { Improper } \\
\text { Hand washing } \\
\text { Hand rub }\end{array}$ & $\begin{array}{c}2 \\
2 \\
18 \\
13\end{array}$ & $\begin{array}{c}5.7 \\
5.7 \\
\mathbf{5 1 . 4} \\
37.1\end{array}$ & $\begin{array}{l}1 \\
1 \\
6 \\
0\end{array}$ & $\begin{array}{c}12.5 \\
12.5 \\
75.0 \\
0.0\end{array}$ & 0.095 & $\begin{array}{c}2 \\
2 \\
18 \\
13\end{array}$ & $\begin{array}{c}5.7 \\
5.7 \\
\mathbf{5 1 . 4} \\
37.1\end{array}$ & $\begin{array}{l}1 \\
1 \\
6 \\
0\end{array}$ & $\begin{array}{c}12.5 \\
12.5 \\
75.0 \\
0.0\end{array}$ & 0.098 \\
\hline & $\begin{array}{c}\text { After touching } \\
\text { patient } \\
\text { surrounding }\end{array}$ & $\begin{array}{c}\text { Missed } \\
\text { Improper } \\
\text { Hand washing } \\
\text { Hand rub }\end{array}$ & $\begin{array}{c}8 \\
1 \\
12 \\
14\end{array}$ & $\begin{array}{c}22.9 \\
2.9 \\
34.3 \\
\mathbf{4 0 . 0}\end{array}$ & $\begin{array}{l}4 \\
0 \\
3 \\
1\end{array}$ & $\begin{array}{c}\mathbf{5 0 . 0} \\
0.0 \\
37.5 \\
12.5\end{array}$ & 0.337 & $\begin{array}{c}12 \\
7 \\
16 \\
0\end{array}$ & $\begin{array}{c}34.3 \\
20.0 \\
45.7 \\
0.0\end{array}$ & $\begin{array}{l}8 \\
0 \\
0 \\
0\end{array}$ & $\begin{array}{c}\mathbf{1 0 0 . 0} \\
0.0 \\
0.0 \\
0.0\end{array}$ & $0.004^{*}$ \\
\hline \multirow{5}{*}{ Opp3 } & $\begin{array}{c}\text { Before touching } \\
\text { patient }\end{array}$ & $\begin{array}{c}\text { Missed } \\
\text { Improper } \\
\text { Hand washing } \\
\text { Hand rub }\end{array}$ & $\begin{array}{c}3 \\
2 \\
22 \\
8\end{array}$ & $\begin{array}{l}8.6 \\
5.7 \\
62.9 \\
22.9\end{array}$ & $\begin{array}{l}1 \\
0 \\
7 \\
0\end{array}$ & $\begin{array}{c}12.5 \\
0.0 \\
87.5 \\
0.0\end{array}$ & 0.423 & $\begin{array}{c}8 \\
8 \\
18 \\
1\end{array}$ & $\begin{array}{c}22.9 \\
22.9 \\
51.4 \\
2.9\end{array}$ & $\begin{array}{l}6 \\
0 \\
2 \\
0\end{array}$ & $\begin{array}{c}75.0 \\
0.0 \\
25.0 \\
0.0\end{array}$ & $0.046^{*}$ \\
\hline & $\begin{array}{c}\text { Before clean/ } \\
\text { aseptic technique }\end{array}$ & $\begin{array}{c}\text { Missed } \\
\text { Improper } \\
\text { Hand washing } \\
\text { Hand rub }\end{array}$ & $\begin{array}{c}4 \\
1 \\
18 \\
12 \\
\end{array}$ & $\begin{array}{c}11.4 \\
2.9 \\
\mathbf{5 1 . 4} \\
34.3 \\
\end{array}$ & $\begin{array}{l}2 \\
0 \\
6 \\
0\end{array}$ & $\begin{array}{c}25.0 \\
0.0 \\
75.0 \\
0.0\end{array}$ & 0.148 & $\begin{array}{c} \\
17 \\
0 \\
18 \\
0\end{array}$ & $\begin{array}{c}48.6 \\
0.0 \\
51.4 \\
0.0\end{array}$ & $\begin{array}{l}8 \\
0 \\
0 \\
0\end{array}$ & $\begin{array}{c}\mathbf{1 0 0 . 0} \\
0.0 \\
0.0 \\
0.0\end{array}$ & $0.013^{*}$ \\
\hline & $\begin{array}{c}\text { After body } \\
\text { fluidexposure risk }\end{array}$ & $\begin{array}{c}\text { Missed } \\
\text { Improper } \\
\text { Hand washing } \\
\text { Hand rub }\end{array}$ & $\begin{array}{c}6 \\
1 \\
19 \\
9\end{array}$ & $\begin{array}{c}17.1 \\
2.9 \\
\mathbf{5 4 . 3} \\
25.7\end{array}$ & $\begin{array}{l}1 \\
0 \\
5 \\
2\end{array}$ & $\begin{array}{l}12.5 \\
0.0 \\
62.5 \\
25.0\end{array}$ & 1.000 & $\begin{array}{c}8 \\
2 \\
25 \\
0\end{array}$ & $\begin{array}{c}22.9 \\
5.7 \\
71.4 \\
0.0\end{array}$ & $\begin{array}{l}3 \\
2 \\
2 \\
1\end{array}$ & $\begin{array}{l}37.5 \\
25.0 \\
25.0 \\
12.5\end{array}$ & $0.013^{*}$ \\
\hline & $\begin{array}{c}\text { After touching } \\
\text { patient }\end{array}$ & $\begin{array}{c}\text { Missed } \\
\text { Improper } \\
\text { Hand washing } \\
\text { Hand rub }\end{array}$ & $\begin{array}{c}4 \\
1 \\
17 \\
13 \\
\end{array}$ & $\begin{array}{c}11.4 \\
2.9 \\
48.6 \\
37.1 \\
\end{array}$ & $\begin{array}{l}3 \\
0 \\
5 \\
0\end{array}$ & $\begin{array}{c}37.5 \\
0.0 \\
62.5 \\
0.0\end{array}$ & 0.065 & $\begin{array}{c}14 \\
2 \\
19 \\
0\end{array}$ & $\begin{array}{c}40.0 \\
5.7 \\
54.3 \\
0.0\end{array}$ & $\begin{array}{l}3 \\
3 \\
1 \\
1\end{array}$ & $\begin{array}{l}37.5 \\
37.5 \\
12.5 \\
12.5\end{array}$ & $0.008^{*}$ \\
\hline & $\begin{array}{c}\text { After touching } \\
\text { patient } \\
\text { surrounding }\end{array}$ & $\begin{array}{c}\text { Missed } \\
\text { Improper } \\
\text { Hand washing } \\
\text { Hand rub }\end{array}$ & $\begin{array}{c}10 \\
1 \\
9 \\
15\end{array}$ & $\begin{array}{c}28.6 \\
2.9 \\
25.7 \\
\mathbf{4 2 . 9}\end{array}$ & $\begin{array}{l}2 \\
2 \\
4 \\
0\end{array}$ & $\begin{array}{c}25.0 \\
25.0 \\
\mathbf{5 0 . 0} \\
0.0\end{array}$ & $0.015^{*}$ & $\begin{array}{c}21 \\
4 \\
10 \\
0\end{array}$ & $\begin{array}{c}\mathbf{6 0 . 0} \\
11.4 \\
28.6 \\
0.0 \\
\end{array}$ & $\begin{array}{l}7 \\
1 \\
0 \\
0\end{array}$ & $\begin{array}{c}\mathbf{8 7 . 5} \\
12.5 \\
0.0 \\
0.0 \\
\end{array}$ & 0.220 \\
\hline
\end{tabular}


The Effect of Hand Hygiene Strategy on Internship Nurses Compliance at Alexandria University ...

Table (2): Distribution of compliance perception of internship nurses regardingHH practice in the 5 indications throughout evening shiftpost strategyone and three monthsin Pediatric and Obstetric\&Gyne at Elshatby hospital. $(\mathrm{n}=43)$

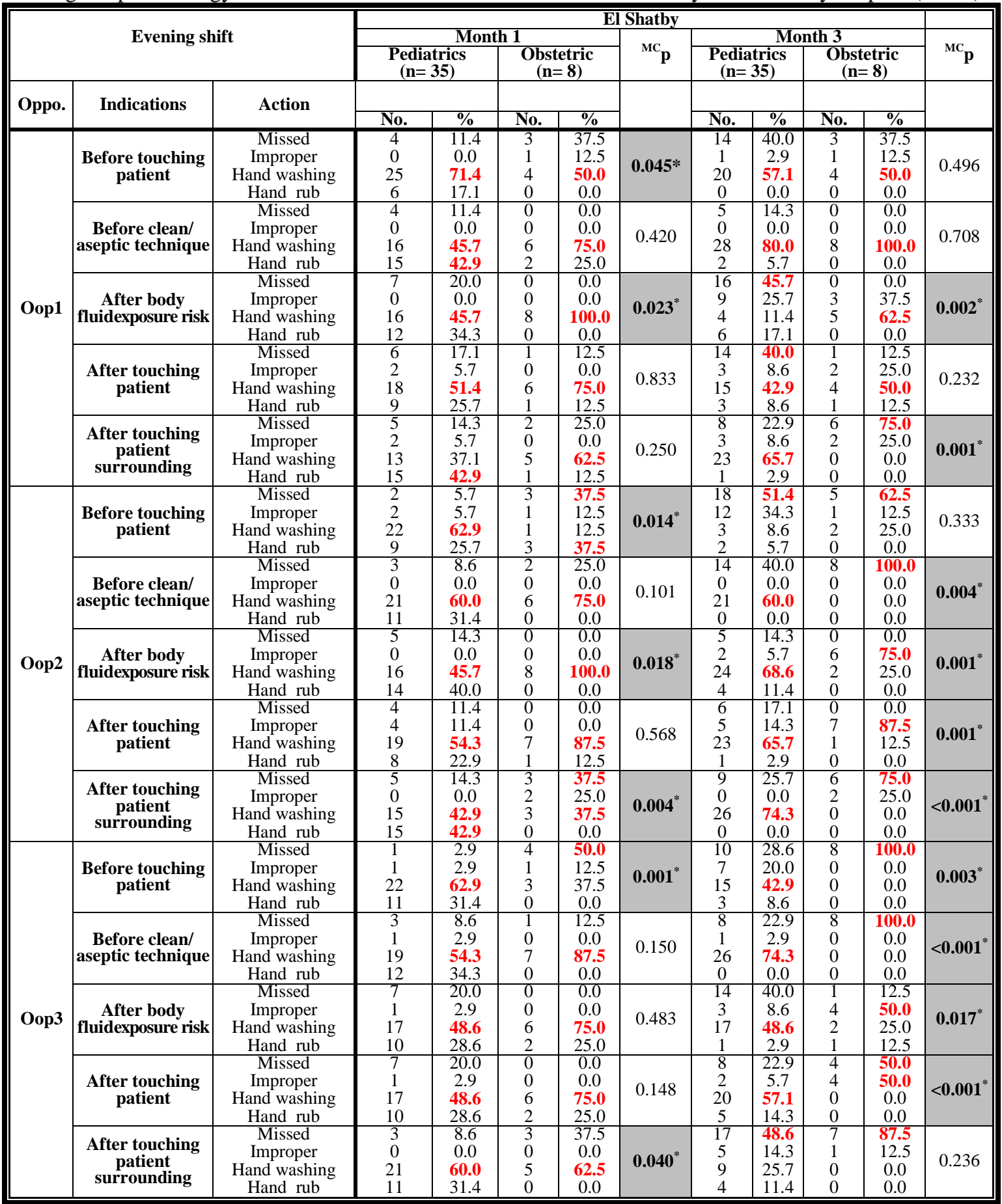

${ }^{\mathrm{MC}} \mathbf{p}<\mathbf{0 . 0 0 1}$ 
The Effect of Hand Hygiene Strategy on Internship Nurses Compliance at Alexandria University ...

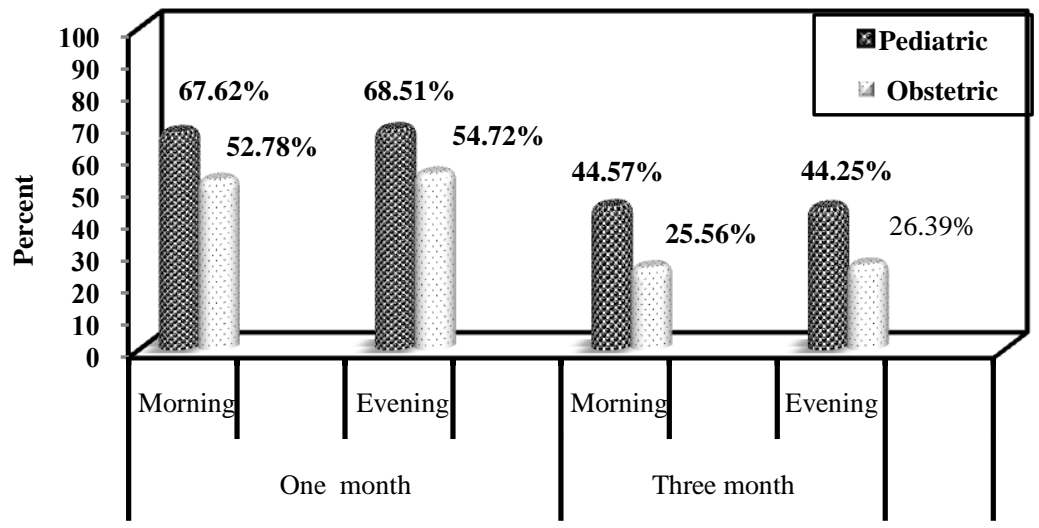

Figure (1): Comparisonbetween the mean value of the compliance perception to HHaction in the5 indications throughout the morning and evening shiftspost strategyone and three months in pediatrics and obstetric departmentsat el shatby hospital.

Table (3):Conveyscomparison among the different departments according to compliance perceptionat the Main University, Smouha, Student, and El-MoassatAlexandria University Hospitals. (n=123)

\begin{tabular}{|c|c|c|c|c|c|c|c|c|c|c|c|c|c|}
\hline \multirow[t]{2}{*}{ Ilouth } & \multirow[t]{2}{*}{ Shift } & \multicolumn{4}{|r|}{ Critical } & \multirow{2}{*}{$\begin{array}{r}\text { Nursing } \\
\text { Adminstration } \\
(\mathrm{N}=4)\end{array}$} & \multicolumn{6}{|c|}{ Medical.Surgical } & \multirow[t]{2}{*}{ Tp } \\
\hline & & $\begin{array}{r}\text { Recorery } \\
(\mathrm{D}=18)\end{array}$ & $\begin{array}{r}\text { Emergency } \\
(\mathrm{ICO}) \\
(\mathrm{N}=\mathrm{s})\end{array}$ & $\begin{array}{r}\text { Thoracic } \\
\text { (ICU) } \\
(\mathrm{N}=4)\end{array}$ & $\begin{array}{r}\text { ICU } \\
(\mathrm{A}=16)\end{array}$ & & $\begin{array}{r}\text { M.edical } \\
(I C D) \\
(\mathrm{N}=9)\end{array}$ & $\begin{array}{r}0, \mathbb{R} \\
\left(\mathrm{N}=\mathbf{n}^{\prime}\right)\end{array}$ & $\begin{array}{l}\text { Neuro } \\
\text { (ICO) } \\
=\text { ")(I) }\end{array}$ & $\begin{array}{r}\text { Burn } \\
\text { (ICO) } \\
(\mathrm{A}=13)\end{array}$ & $\begin{array}{r}\text { Trology } \\
(\mathrm{ICO}) \\
(\mathrm{N}=3)\end{array}$ & $\begin{array}{r}\text { Dialyyis } \\
\left(\mathrm{N}^{\prime}=9\right)\end{array}$ & \\
\hline \multirow{8}{*}{$\begin{array}{l}0 \\
0 \\
0\end{array}$} & Morning & & & & & & & & & & & & \\
\hline & Oop! & $52.36=24.68$ & $62.67=18.62$ & $53.33=1.40$ & $57.92=24.55$ & $51.67=6.38$ & $57.04=17.36$ & $70.60^{\circ}=16.06$ & $40.95=20.16$ & $53.33=21.43$ & $55.56=10.18$ & $45.93=1.9 .85$ & 0.604 \\
\hline & Oop? & $60.0=20.63$ & $62.67=25.21$ & $51.61=13.74$ & $72.92=13.87$ & $50.0=8.6 !$ & $37.04=1.4 .95$ & $40.0=16.33$ & $37.14=1.268$ & $41.03=13.01$ & $53.33=6.67$ & $43.70=17,36$ & $\$ 0,001$ \\
\hline & Oop? & $57.08=26.56$ & 56.017 .38 & $53333=15.40$ & $70.0 \pm 10.33$ & $45.0=6.38$ & $42.96=133.38$ & $46.67=28.67$ & $39.05=15.60$ & $47.69=1.9 .22$ & $46.67=11.55$ & $40.0 \pm 27.69$ & 0,028 \\
\hline & Erening & & & & & & & & & & & & \\
\hline & Oopl. & $63.06=24.98$ & $38.67=12.82$ & $61.67 \pm 16.67$ & $80.0=8.78$ & $65.0=12.62$ & $60.0=14.14$ & $72.0=15.20$ & $40.95=17.82$ & $51.28=20.80$ & $48.89=7.70$ & $44.44=19.72$ & 0,001 \\
\hline & Oop? & $59.03=23.58$ & $66.67=20.0$ & $50.0=11.55$ & $75.42=6.76$ & $65.0=12.62$ & $45.19=24.67$ & 52.024 .68 & $29.52=12.68$ & $43.08=20.11$ & $48.89=3.85$ & $45.93=16.81$ & 40,001 \\
\hline & Oop? & $61.67=25.38$ & 36.021 .40 & $53.33=16.33$ & $77.50=9.07$ & $63.33=1.55$ & $40.0=11.06$ & $52.0=30.33$ & $37.14=20.68$ & $52.31=19.4 !$ & $60.0 \pm 1.55$ & $53.33=24.49$ & 0,002 \\
\hline \multirow{8}{*}{$\begin{array}{l}3 \\
0\end{array}$} & Moruing & & & & & & & & & & & & \\
\hline & Oop! & $4.81=18.18$ & $40.0 \pm 18.86$ & $18.33=18.36$ & $39.58=1.29$ & $15.0 \pm 1.39$ & $31.85=2255$ & $77.33=18.62$ & $35.24=19.52$ & $23.08=19.55$ & $37.78=10.18$ & $13.33=1333$ & 0,033 \\
\hline & Oop? & $41.81=19.29$ & $78.67=11.93$ & $21.67=22.03$ & $57.50=16.31$ & $25.0 \pm 17.53$ & $52.59=13.92$ & $30.67=23.85$ & $45.71=18.23$ & $23.99=10.75$ & $46.67=0.67$ & $19.26=11.28$ & 80,001 \\
\hline & Oop? & $35.56=18.77$ & $22.67 \pm 16.73$ & $26.67=18.86$ & $52.08=17.42$ & $18.33=10.0$ & $38.52=10.42$ & $70.67=23.85$ & $38.10=13.72$ & $13.33=9.8 !$ & $28.89=1.925$ & $22.22=3.77$ & 40,001 \\
\hline & Erening & & & & & & & & & & & & \\
\hline & Oopl. & $50.97=21.72$ & 56.012.1II & 30.0227 .49 & $60.42=13.4$ & $18.33=10.0$ & $51,11=12.47$ & $30.67=16.06$ & $8.51 \pm 1.36$ & $77.44=16.90$ & 42.2210 .18 & $7.4: 1.7 .78$ & 40,001 \\
\hline & Oop? & $47.36=20.32$ & $46.67=9.43$ & $43.33=20.0$ & 50.021 .50 & $21.6=10.0$ & $45.19=17.57$ & $33.33=20.0$ & $73.33=1678$ & $12,31=9.75$ & $53.33=1333$ & $14.07=11.28$ & 40,001 \\
\hline & Oop? & $49.58=25.80$ & $24.0 \pm .96$ & $31.67=27.42$ & $52.08=1.485$ & $20.0 \pm 10.89$ & $33.33=1.53$ & $29.33 \pm 1738$ & $70.48=1.4 .84$ & $15.38=1.2 .24$ & $62.22=21.43$ & $77.78=12.99$ & $\$ 0,001$ \\
\hline
\end{tabular}

*: Statistically Significant At $\mathbf{P} \leq \mathbf{0 . 0 5}$

Table (4): Comparison among the different departments according to compliance perceptionat El hadaraHospital: $(\mathbf{n}=\mathbf{2 4})$

\begin{tabular}{|c|c|c|c|c|c|c|}
\hline \multirow[b]{2}{*}{$\begin{array}{l}\text { Follow } \\
\text { Up }\end{array}$} & \multirow[t]{2}{*}{ Shift } & \multicolumn{3}{|c|}{ EL HadaraHospital } & \multirow[t]{2}{*}{$\mathbf{F}$} & \multirow[t]{2}{*}{$\mathbf{P}$} \\
\hline & & $\begin{array}{c}\text { Orthopedic } \\
\text { (ICU) } \\
(\mathbf{N}=8)\end{array}$ & $\begin{array}{c}\text { Critical \&Epilepsy } \\
\text { Medicine(ICU) } \\
(\mathrm{N}=4)\end{array}$ & $\begin{array}{l}\text { Neuro-Pschiatry(ICU) } \\
(\mathrm{N}=12)\end{array}$ & & \\
\hline \multirow{8}{*}{ 㲵 } & Morning & & & & & + \\
\hline & Oop1 & $67.50 \pm 17.97$ & $73.33 \pm 9.43$ & $61.67 \pm 9.48$ & 1.355 & 0.280 \\
\hline & Oop2 & $69.17 \pm 6.11$ & $63.33 \pm 6.67$ & $58.33 \pm 9.48$ & $4.287^{*}$ & $0.027^{*}$ \\
\hline & Oop3 & $72.50 \pm 10.35$ & $73.33 \pm 9.43$ & $61.11 \pm 10.57$ & 3.826 & $\mathbf{0 . 0 3 8}^{*}$ \\
\hline & Evening & & & & & \\
\hline & Oop1 & $69.17 \pm 10.65$ & $75.0 \pm 10.0$ & $66.11 \pm 13.77$ & 0.795 & 0.465 \\
\hline & Oop2 & $70.0 \pm 11.82$ & $81.67 \pm 10.0$ & $63.33 \pm 12.23$ & $3.706^{*}$ & $0.042^{*}$ \\
\hline & Oop3 & $77.50 \pm 10.65$ & $65.0 \pm 16.67$ & $63.89 \pm 11.18$ & 3.329 & 0.055 \\
\hline \multirow{8}{*}{ 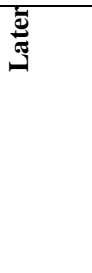 } & Morning & & & & & \\
\hline & Oop1 & $37.50 \pm 18.49$ & $37.22 \pm 17.63$ & $33.33 \pm 23.09$ & 0.076 & 0.927 \\
\hline & Oop2 & $12.50 \pm 5.56$ & $37.22 \pm 13.77$ & $36.67 \pm 17.64$ & $10.464^{*}$ & $0.001^{*}$ \\
\hline & Oop3 & $20.0 \pm 20.16$ & $42.78 \pm 14.90$ & $33.33 \pm 19.63$ & $4.061^{*}$ & $0.032^{*}$ \\
\hline & Evening & & & & & \\
\hline & Oop1 & $31.67 \pm 19.44$ & $45.0 \pm 27.95$ & $30.0 \pm 15.70$ & 0.952 & 0.402 \\
\hline & Oop2 & $11.67 \pm 11.68$ & $30.0 \pm 19.25$ & $36.11 \pm 20.59$ & $4.545^{*}$ & $0.023^{*}$ \\
\hline & Oop3 & $20.0 \pm 18.86$ & $33.33 \pm 18.05$ & $28.33 \pm 17.09$ & 0.888 & 0.426 \\
\hline
\end{tabular}


The Effect of Hand Hygiene Strategy on Internship Nurses Compliance at Alexandria University ...

F: F Value for ANOVA Test

*: Statistically Significant At P $\leq \mathbf{0 . 0 5}$

Table (5): Distributionof studied sample according to the percentage of compliance to $\mathrm{HH}$ action in all 5 indications through the morning shift in the Main University/Elhadara hospital after one month and three months post $\mathrm{HH}$ intervention. ( $\mathrm{n}=147)$

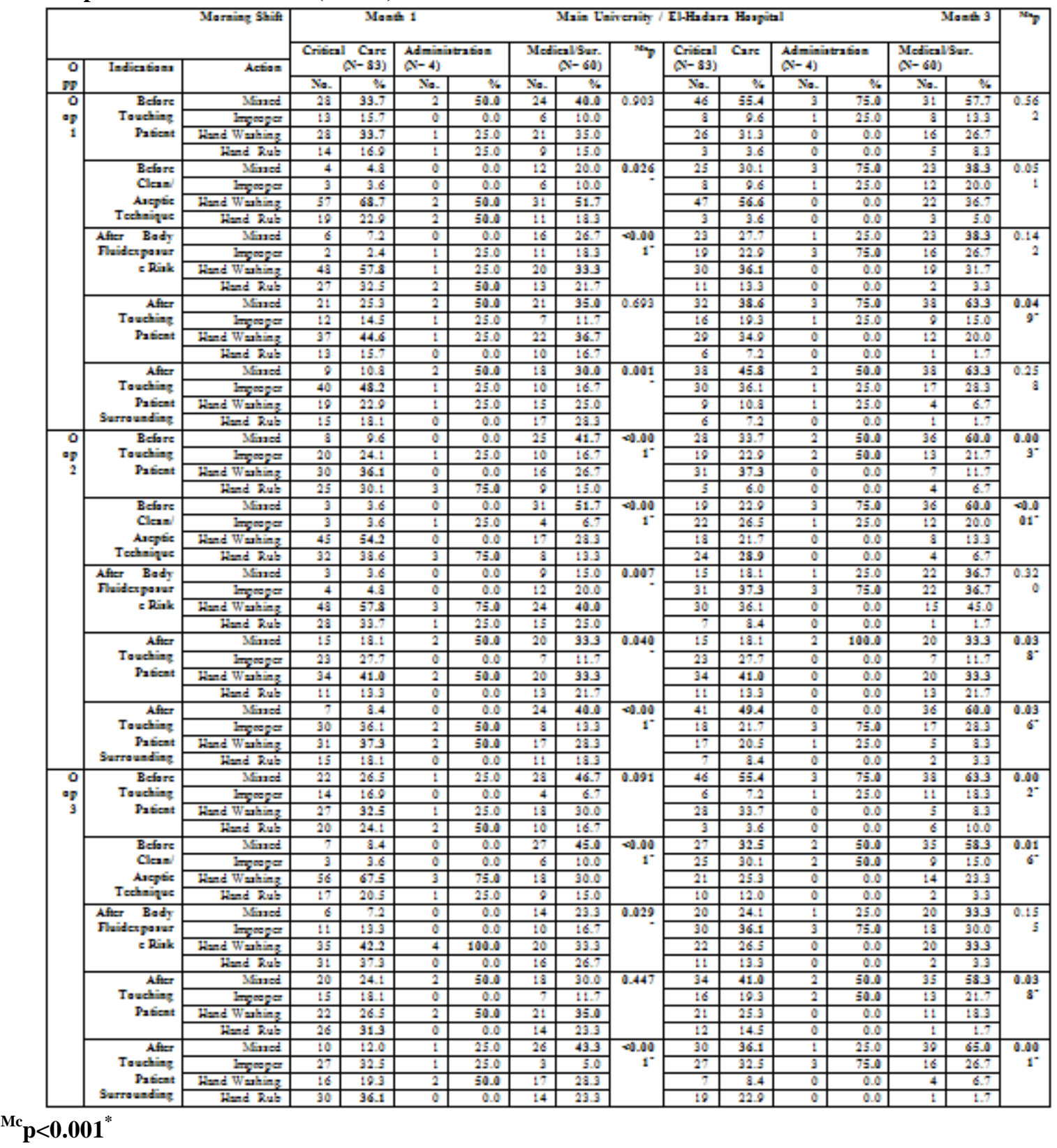


The Effect of Hand Hygiene Strategy on Internship Nurses Compliance at Alexandria University ...

Table (6): Distribution of studied sample according to the percentage of compliance to $\mathrm{HH}$ action in all 5 indications through the evening shift in the Main University/Elhadara hospital after one month and three months post $\mathrm{HH}$ intervention.( $\mathrm{N}=147)$
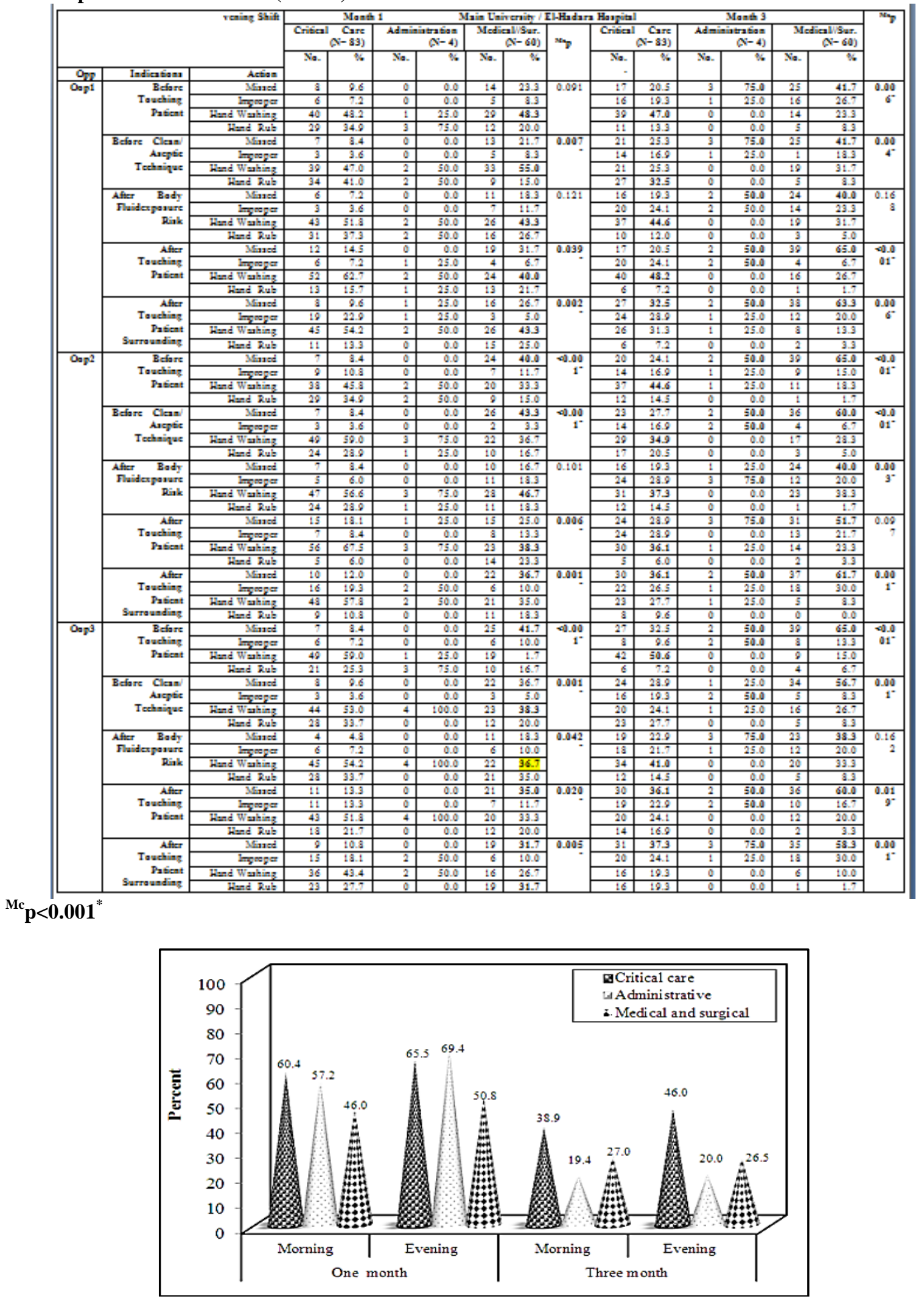

Figure (2) : Comparison between the mean value of the compliance perception of internship nurses regardingHH practice in the 5 indications throughout morning and evening shifts post strategyone and three monthsin Critical, Administration, and Medical- Surgical departments 


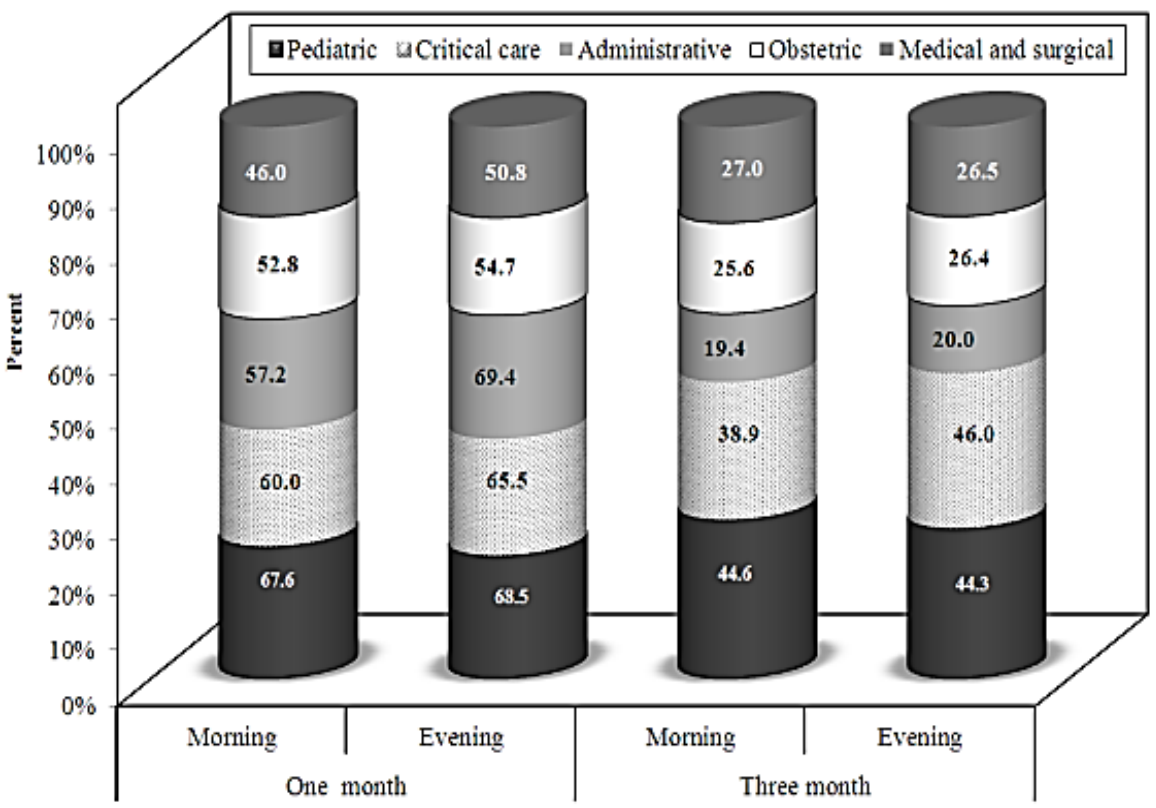

Figure (3): Comparison between different departments in the three hospitals according to the compliance perception of internship nurses regardingHH practice in the 5 indications throughout morning and evening shifts post strategyone and three months.

\section{Discussion}

Hand Hygiene at five moments is considered the easiest way to anticipate the dissemination of infection. However, improving hand washing compliance and maintaining this behavioral change is a significant challenge, because of the complexities of the health care environment and changing behavior ${ }^{(25)}$. Numerous studies have documented the pivotal role of healthcare workers' (HCWS) hands in the propagationof micro-organisms within the healthcare environment and ultimately to patients ${ }^{(26,27)}$.

The current study showed a dramatic improvement in hand hygiene practice among the internship students nurses one month post HH interventional strategy. After one month at the morning,thepercent ofhand washing compliance among more than half of the internship nurses was obvious in Pediatric department. In relation to Obstetric\&Gyne department, the results showed that more than half of the internship nurses were complied to hand washing in some indications, nevertheless more than one third did not comply especially before touching patients and theirsurroundings.

These findingsare supported by a study done byAbdelaziz, and Bakr (2009)to assess knowledge, attitude and practice of hand washing among HCWS in AinShams University hospitals in Cairo ${ }^{(28)}$.They found that the percent of compliance to HH in Pediatrics (NICU )was 62.5\% and 39.4\% in Gynecology .These results were compared with Won (2004) study in a teaching hospital where he found compliance to hand hygiene in NICU was $43 \%{ }^{(29)}$.a similar study was conducted by Mahfouz et al (2013) on non-compliance among ICU unit HCWs in Aseer Central Hospital, south-western Saudi Arabia.They found that, higher levels of non-compliance were found before patient contact ${ }^{(30)}$. the WHO indicated poor levels of compliance before aseptic task and was suggested that high risk activities have lower compliance ${ }^{(31,32)}$.Also, Allegranzi and Pittet (2009) reported that HCWScompliance was high when hands were visibly dirty or sticky ${ }^{(33)}$.

Unfortunately, this compliance was reduced three months from the educational intervention. The findings showed that thepercent ofhand washing compliancewas decreased in Pediatrics as compared to earlier assessment. This could be explained by work overload, visitors' inflow, and availability of facilities. This is in agreement with a studyby Cantrel, et al (2009) on HH compliance by physicians: marked heterogeneity due to local culture?that $81 \%$ of hospital hand hygiene compliance rate post-intervention phase, decreased after six months to be $59 \%{ }^{(34)}$. The current results showed that the majority of nurses were more likely to use soap and water compared to alcohol-based hand hygiene disinfectant in Pediatric and Obstetric \&Gynecologicdepartment. These findings were congruent with the results of a study byKaraaslan, et al. (2014) WHO examined the compliance of HCWSwith HH practices in Neonatal and Pediatric ICU andconcluded that HCWS preferred to use soap and preferred water instead of alcohol-based hand hygiene disinfectant ${ }^{(35)}$.Alcohol-based disinfectants were notpreferred probably because of the unpleasant irritation effects on the hands and lack of knowledge concerning its benefits. 
Thecurrent results denoted that no marked differences between the morning and evening shifts in relation to $\mathrm{HH}$ compliance in both Pediatrics and Obstetric\& Gynecologicdepartments one month and three months post intervention. Chavali, et al. (2014) also noted no difference in compliance rates between day and night times ${ }^{(36)}$. When comparingthemean percent score of nurses' compliance in the Pediatric and Obstetric \& gynecologic departments, the results concluded thatpediatric nurses' scores were much better than the obstetric one month as well as three months poststrategyat both the morning and evening shifts. Cantrell, et al. (2009) postulated that the highest rate of compliance with $\mathrm{HH}$ practices was seen in a Neonatal ICU and the lowest rate at Obstetrics and Gynecology ${ }^{(34)}$. This is likely due to multiple factors, as discussed by Pittet et al, (2004) including differences in local culture and role modeling by senior physicians at different sites ${ }^{(37)}$ Sansam , et al (2016) emphasized that HCWS must appreciate that children tend to be easily infected ${ }^{(38)}$.

Unfortunately, compliance to hand hygiene guidelines was the lowest in Critical care areas, though those patient are highly vulnerable to infection. So, asserting HCWSknowledge and awareness grant them efficiently ameliorated compliance with hand hygiene ${ }^{(39,40)}$. The present study findings showed statistical significant differencesamong the Critical, Administration, and Medical-Surgical departmentsat bothmorning and evening shifts. The mean percent score of the internship nurses compliance to $\mathrm{HH}$ action in the Critical care department was much better than the Administration and Medical- Surgical department. Forevening shift, the Administration department showed higher mean percent score of compliance than those in the other two departmentsa study done by Mathai, et al. (2011) in a tertiary level ICU, found that HH compliance between health care workers in the ICU was poor before a $\mathrm{HH}$ interventional strategy, but the overall compliance improved significantly following the intervention ${ }^{(41)}$.

After three months of the current studied strategy, there was a significant decline in the mean percent score of nurses' compliance to $\mathrm{HH}$ action in the three studied departments. The majority of the internship nurses were less likely compliant to HH. This could be explained by lack of periodic students' observation, guidance, role models,and lack of incentives, and intuitional guidelinesthat might becontributing factors to these results. These resultswere in congruent with a study by Silva, et al. (2007) who did not find any effect after three months of education ${ }^{(39)}$. In this regard, Wandel et al. (2010)claimed that enhancing HH compliance was not achieved neither with a high level of knowledge nor with social influence ${ }^{(40)}$. In contrast to these findings, Silmah, et al. (2016), and Ahmed, et al. (2006) reported greatest improvement in HH knowledge and compliance among hcws immediately and three months following a hospital-wide educational intervention $^{(42,43)}$ average adherence with $\mathrm{HH}$ recommendations is usually estimated to be below, but varies between different hospital departments, among professional categories, and according to working conditions ${ }^{(44)}$. The higher the workload, that is the number of opportunities for hand hygiene per hour of patient care, the lower the compliance ${ }^{(45) \text {. }}$

In a comparison between the different departments atElshatby, Main-university, and Elhadara hospitals in which the internship student nurses have trained, the results revealed that one and three months post $\mathrm{HH}$ interventional strategy, the highest mean percent score of nurses compliance was in the pediatrics, followed by Critical care, Administrative, and Obstetric\&Gynecologic. TheMedical- Surgical department had the lowest mean percent score of complianceat both morning and evening shifts.A similar interventional study by Slimah, et al. (2016) to assess HH and health care associated infection, found that (PICU) was more likely to have high HHcompliance compared to (ICU) and Medical -Surgical units ${ }^{(42)}$. Incontrast to the current study findings, Tomar, et al. (2015) concluded that HH compliance of HCWS in PICU was very poor ${ }^{(46)}$. Prevention and control of HAI remain major priorities for countries around the world. It can effectively be advanced through the simple and inexpensive hygiene practice of proper handwashing between patient contact by doctors, nurses, health assistants and other support staff. Whatever their reason for failing to wash their hands at critical times, health workers who spread HAI stand guilty of violating the Hippocratic oath, do no harm, that is sacred to their profession, and should therefore be made accountable in the most appropriate way ${ }^{(47)}$.

\section{Conclusions}

Based on the findings of the present study, it can be concluded thatinternshipnurses compliancewas high in some departments after one month, and the percent score of compliance was declined after three months post $\mathrm{HH}$ interventional strategy. No marked differences were found between morning and evening shifts in relation to compliance in some departments.

\section{Recommendations}

The following recommendations are forwarded:

1. Implementation of hand washing training strategies for undergraduate students, doctors, and nurses would improve $\mathrm{HH}$ practices.

2. Compliance strategies developed should be implemented early in training periodically in the graduation and clinical courses for internship nurses. 
3. Continuing monitoring and clinical performance appraisal is beneficial,increase in supplies necessary for hand washing and institutional supports are required.

\section{References}

[1]. Trampuz A, Widmer AF. Hand Hygiene: A Frequently Missed Life Saving Opportunity During Patient Care. Mayo Clin Proc. 2004; 79:109-16.

[2]. Burke JP. Infection Control: A Problem For Patient Safety. N Engl J Med. 2003; 348: 651-56

[3]. World Health Organization. Improved Hand Hygiene To Prevent Healthcare-Associated Infections. Patient Safety Solutions. 2007, Available At: Http://Www.Who.Int/Gpsc/Tools/Faqs/Evidence_Hand_Hygiene/En/.

[4]. Allegranzi B., Pittetd. Role Of Hand Hygiene In Healthcare-Associatedinfection Prevention .Journal Of Hospital Infection 2009; 73: 305-15.

[5]. World Health Organization Patient Safety. WHO Guidelines On Hand Hygiene In Health Care: A Summary. Geneva, Switzerland: World Health Organization; 2009.

[6]. Dasgupta S, Das S, Chawan N, Hazra A. Nosocomial Infections In The Intensive Care Unit: Incidence, Risk Factors, Outcome And Associated Pathogens In A Public Tertiary Teaching Hospital Of Eastern India.Indian J Crit Care Med. 2015 Jan; 19(1): 14-20.

[7]. National Guideline On Hand Hygiene For Prevention Of Hospital Acquired Infection. StrategymeManager Hand Hygiene \& Surgical Care Who Ban Activity 2010-2011.

[8]. Pittet D, Allegranzi B, Sax H, Et Al. Evidence-Based Model For Hand Transmission During Patient Care And The Role Of Improved Practices. Lancet Infect Dis. 2006; 6:641-52

[9]. Pittet D, Boyce J. Hand Hygiene During Patient Care: Pursuing The SemmelweisLegacy. Lancet Infect Dis. 2001 ; April: 9-20.

[10]. Siegel JD, Rhinehart E, Jackson M, Chiarello L. Guideline For Isolation Precautions: Preventing Transmission Of Infectious Agents In Health Care Settings. Am J Infect Control 2007;35(2):S65-S164.

[11]. Pronovost P, Needham D, Berenholtz S, Et Al. An Intervention To Decrease Catheter-Related Bloodstream Infections In The ICU. N Engl J Med .2006;335:2725-2732.

[12]. Pittet D. Hand Hygiene: It's All About When And How. Infect Control Hospepidemiol. 2008; 29:957-9

[13]. WHO Guidelines On Hand Hygiene In Health Care First Global Patient Safety Challenge Clean Care Is Safer Care. 2009. Http://Whqlibdoc.Who.Int/Publications/2009/9789241597906_Eng.Pdf.

[14]. Pittetd. Hand Hygiene: Improved Standards And Practice For Hospital Care 2003 Lippincott Williams \&Wilkins. 327-35.

[15]. Kennedy A., Elward A., Fraser V. Survey Of Knowledge, Beliefs And Practices Of Neonatal Intensive Care Unit Healthcare Workers Regarding Nosocomial Infections, Central Venous Catheter Care And Hand Hygiene. Infection Control And Hospital Epidemiology 2004; 25 (9):747-52.

[16]. Kennedy M., Burnett E. Hand Hygiene, Knowledge And Attitudes :Comparison Between Student Nurses. Journal OfInfection Prevention. 2011; 12:246-250

[17]. Pittet D. Improving Adherence To Hand Hygiene Practices. Emerg Infect Dis. 2011; 7: 234-40.

[18]. Snow M, White G, Alder S, Stanford J. Mentor's Hand Hygiene Practices Influence Student's Hand Hygiene Rates. American Journal OfInfection Control 2006; 34(1):18-24.

[19]. Mortelv, Kermode S, Progano T, Sansoni J. A Comparison Of The Hand Hygiene Knowledge, Beliefs And Practices Of Italian Nursing And Medical Students. Journal OfAdvanced Nursing. 2012; 68(3):569-79.

[20]. Centers ForDisease Control And Prevention (CDC). Guideline For Hand Hygiene In Healthcare Settings. MMWR Morbidity AndMortality Weekly Report2002; 51(16): 1-44.

[21]. Gould DJ, Moralejo D, Drey N, Chudleigh JH. Interventions To Improve Hand Hygiene Compliance In Patient Care. Cochrane Database Of Systematic Reviews 2010, Issue 9.

[22]. Sax H, Allegranzi B, Uçkay I, Et Al. 'My Five Moments For Hand Hygiene': A User-Centred Design Approach To Understand, Train, Monitor And Report Hand Hygiene. Journal Of Hospital Infection2007;67(1):9-21.

[23]. Ariyaratnem ,Gunasekarat, Weerasekaram , Et Al . Knowledge, Attitudes And Practices Of Hand Hygiene Among Final Year Medical And Nursing Students At The University Of Sri Jayewardenepura. Sri Lankan Journal Of Infectious Diseases 2013; .3(1);15-25.

[24]. Lee K. Student And Infection Prevention And Control Nurses' Hand Hygiene Decision Making In Simulated Clinical Scenarios: A Qualitative Research Study Of Hand Washing, Gel And Glove Use Choices. Journal OfInfection Prevention 2013 ; 14 (3):96-103.

[25]. Terrace L. Measuring Hand Hygiene Adherence: Overcoming The Challenges. The Joint Commission; TheJoint Commission. Infection Control. 2009. Its Monograph (Book).

[26]. Gazal S. Knowledge And Behaviors Related To Hand Hygiene Among Al-Assad University Hospital Nurses. Tishreen University Journal For Research And Scientific Studies - Health Sciences2015;37(1):51-69.

[27]. WHO Guidelines For Hand Hygiene In Health Care (Advanced Draft). Geneva: World Health Organization (2006).

[28]. Abdelaziz K, Bakr I. Assessment Of Knowledge, Attitude And Practice Of Hand Washing Among Health Care Workers In Ain Shams University Hospitals In Cairo . J Prev Med Hyg. 2009; 50: 19-25.

[29]. Won SP, Chou HC, Hsieh WS, Et Al. Hand-Washing Strategy For The Prevention Of Nosocomial Infections In A Neonatal Intensive Care Unit. Infect Control Hosp Epidemiology 2004; 25:742-6.

[30]. Mahfouz AA, El Gamalmn,Al-AzraqiTA.HandHygiene Non-Compliance Among Intensive Care Unit Health Care Workers In Aseer Central Hospital, South-Western Saudi Arabia.Int J Infect Dis. 2013 ;17(9):729-32.

[31]. Erasmus V, Daha TJ, Brug H, Richardus JH, Behrendt MD, Vos MC, Et Al. Systematic Review Of Studies On Compliance With Hand Hygiene Guidelines In Hospital Care. Infect Control Hospepidemiol 2010;31:283-94.

[32]. World Health Organization. Guidelines On Hand Hygiene In Health Care. First Global Patient Safety Challenge: Clean Care Is Safer Care. Geneva: WHO; 2009.

[33]. Allegranzi B, Pittet D. The Role Of Hand Hygiene In Healthcare-Associated Infection Prevention. J Hosp Infect 2009;73:305-15.

[34]. Cantrell D Cantrell, MD,Aodedshamriz, MD,AmatanJ. Cohen, MD, MPH,AzviStern, MD,B Colin Block, Mbbch, Phd,C And Mayer Brezis, MD, Mpha,D. Hand Hygiene Compliance By Physicians: Marked Heterogeneity Due To Local Culture? (Am J Infect Control 2009;37:301-5.)

[35]. Karaaslan A, Kadayifci E, Sili U, Et Al.ComplianceOf Healthcare Workers With Hand Hygiene Practices In Neonatal And Pediatric Intensive Care Units: Overt Observation.Interdisciplinary Perspectives OnInfectious Diseases 2014; 2014:1-5. Chavali S, Menon V, Shukla U. Hand Hygiene Compliance AmongHealthcare Workers In An Accredited Tertiary Care Hospital.Indian J Crit Care Med. 2014; 18(10): 689-93. 
[36]. Pittet D, Simon A, Hugonnet S, Pessoa-Silva CL, Sauvan V, Perneger TV. Hand Hygiene Among Physicians: Performance, Beliefs, And Perceptions. Ann Intern Med 2004;141:1-8

[37]. Sansam S, Yamamoto E, Srun S, Et Al..AssessmentOf Hand Hygiene Compliance After Hand Hygiene Education Among Health Care Workers In Cambodia. Nagoya J Med Sci. 2016; 78(2): 151-62.

[38]. Silva P, Hugonnet S., Pfister R., Et Al. Reduction Of Health Care Associated Infection Risk In Neonates By Successful Hand Hygiene Promotion. Pediatrics2007; 120(2):382-90.

[39]. Wandel D., Maes, L., Labeau, S., Et Al..Behavioral Determinants Of Hand Hygiene Compliance In Intensive Care Units. American Journal OfCritical Care2010; 19(3), 230-39.

[40]. Mathai A, George E, AbrahamJ.EfficacyOf A Multimodal Intervention Strategy In Improving Hand Hygiene Compliance In A Tertiary Level Intensive Care Unit.Indian J Crit Care 2011; 15(1): 6-15.

[41]. Slimah N., Milaatw, Ramadan E, Et Al.Hand Hygiene And Health Care Associated Infection: An Intervention Study.American Journal Of Medicine And Medical Sciences 2016, 6(1): 7-15

[42]. Ahmed QA, Memish ZA, Allegranzi B, Pittet D WHO Global Patient Safety Challenge. Muslim Health-Care Workers And Alcohol-Based Handrubs. Lancet 2006 25; (367): 1025-7.

[43]. Boyce JM, Pittet D, Healthcare Infection Control Practices Advisory Committee. Guideline ForHand Hygiene In Health-Care Settings. Recommendations of The Healthcare Infection Control Practices Advisory Committee And The HIPAC/SHEA/APIC/IDSA Hand Hygiene Task Force.Am J Infect Control. 2002 ; 30(8):S1-46.

[44]. Saloojee H, Steenhoff A. The Health Professional's Role In Preventing Nosocomial Infections. Postgraduate Medical Journal. 2001; $77: 16-19$.

[45]. Tomar S, Lodha R, Das B, Kapil A. Hand Hygiene Compliance Of Healthcare Workers In A Pediatric Intensive Care Unit .Indian Pediatrics 2015; 52(15)620-21.

[46]. Samuelr, Almedoma, Hagosg, Albin, Mutungia. Promotion Of Handwashing As A Measure Of Quality Of Care And Prevention Of Hospital- Acquired Infections In Eritrea: The KerenStudy.Afr Health Sci.2005 ; 5(1): 4-13. 